\title{
Activation of Phenotypic Subpopulations in Response to Ciprofloxacin Treatment in Acinetobacter baumannii
}

\author{
Ashley E. MacGuire ${ }^{1}$, Meining Carly Ching ${ }^{1}$, Brett H. Diamond ${ }^{1}$, Alexey Kazakov ${ }^{2}$, Pavel \\ Novichkov ${ }^{2}$, and Veronica G. Godoy $1{ }^{1,}$ \\ ${ }^{1}$ Department of Biology, Northeastern University, Boston, Massachusetts, USA \\ ${ }^{2}$ Lawrence Berkeley National Laboratory, Berkeley, California, USA
}

\section{Summary}

The multidrug-resistant, opportunistic pathogen, Acinetobacter baumannii, has spread swiftly through hospitals worldwide. Previously, we demonstrated that $A$. baumannii regulates the expression of various genes in response to DNA damage. Some of these regulated genes, especially those encoding the multiple error-prone DNA polymerases, can be implicated in induced mutagenesis, leading to antibiotic resistance. Here, we further explore the DNA damageinducible system at the single cell level using chromosomal transcriptional reporters for selected DNA damage response genes. We found the genes examined respond in a bimodal fashion to ciprofloxacin treatment, forming two phenotypic subpopulations: induced and uninduced. This bimodal response to ciprofloxacin treatment in A. baumannii is unique and quite different than the Escherichia coli paradigm. The subpopulations are not genetically different, with each subpopulation returning to a starting state and differentiating with repeated treatment. We then identified a palindromic motif upstream of certain DNA damage response genes, and have shown alterations to this sequence to diminish the bimodal induction in response to DNA damaging treatment. Lastly, we are able to show a biological advantage for a bimodal response, finding that one subpopulation survives ciprofloxacin treatment better than the other.

\section{Introduction}

Acinetobacter baumannii has gained notoriety in recent years as a nosocomial pathogen (Munoz-Price \& Weinstein, 2008). Causing pneumonia, meningitis and severe wound infections in immunocompromised patients (Dijkshoorn et al., 2007), A. baumannii is able to persist in the hospital environment by resisting disinfection and desiccation (Jawad et al., 1998, Musa et al., 1990). Compounding the problem, antibiotic resistance is on the rise among A. baumannii strains, with some emerging strains showing resistance to all clinically relevant antibiotics (Doi et al., 2009, Park et al., 2009).

It has been shown that the genome of A. baumannii is readily changeable through the incorporation of insertion sequences, transposons and genetic material horizontally

*Corresponding Author: 134 Mugar Life Science Building, 360 Huntington Avenue, Boston, MA 02115, v.godoycarter@ neu.edu, Telephone: (617) 373-4042, Fax: (617) 373-3724.

Competing Interests: The authors declare no competing interests. 
transferred from other organisms (Peleg et al., 2008, Mugnier et al., 2010). This ease of acquisition and incorporation of foreign genetic material facilitates the rapid adjustment of this bacterium to new antibiotic treatments and ultimately determines its success as a pathogen (Hornsey et al., 2011, Hua et al., 2012, Adams et al., 2010). While other organisms utilize numerous systems to preserve genomic stability, A. baumannii appears to favor genomic plasticity. With this knowledge, it was intriguing that $A$. baumannii appears to lack a DNA damage response system, known to contribute, in other systems, to mutagenesis and genetic flexibility under certain conditions (Ubeda et al., 2005, Friedberg et al., 2006). Such systems have been researched extensively, Escherichia coli being the paradigm, in which over 40 genes, coding for proteins predominantly involved in DNA repair, mutagenesis and growth cycle arrest are simultaneously regulated by the global regulator LexA (Courcelle et al., 2001, Little et al., 1980, Little et al., 1981). In E. coli, DNA damage response induction begins with the DNA damage-dependent accumulation of single stranded DNA (ssDNA). RecA coats this ssDNA, forming the RecA nucleoprotein filament. Finally, interaction of LexA with the RecA nucleoprotein filament promotes cleavage of the DNA damage response repressor, LexA, resulting in the concerted induction of the DNA damage response genes in both whole populations and individual cells (Walker et al., 1985, Friedman et al., 2005).

Initially, it was thought that there was no DNA damage response system in Acinetobacter spp. due to the lack of genes normally associated with this type of response, such as the global repressor, lexA and the cell division factor, sulA (Robinson et al., 2010). However, several groups have linked the induction of certain genes to DNA damage within the Acinetobacter genus (Rauch et al., 1996, Hare et al., 2006, Aranda et al., 2013) and have shown the capacity for DNA damage-induced mutagenesis within the A. baumannii species (Hare et al., 2012). We have recently shown the RecA-dependent regulation of multiple copies of genes encoding error-prone, Y-family DNA polymerases in response to DNA damage in A. baumannii. Additionally, these proteins seem to be involved in DNA damageor desiccation-induced mutagenesis, leading to antibiotic resistance (Norton et al., 2013). Because the A. baumannii $\Delta r e c A$ strain we used is not a complete deletion, we also observed elevated $r e c A$ transcript in the absence of a functional RecA protein, contradicting conventional DNA damage system induction. Though the full elucidation of the DNA damage system in A. baumannii is unfinished, the lack of a LexA-like repressor, the existence of multiple copies of error-prone polymerases and the RecA-independent induction of recA, indicate that A. baumannii possesses a DNA damage response that is different from the defined $E$. coli paradigm (Norton et al., 2013). A recent work by Aranda et al., suggested that the A1S_1389 gene might be the missing LexA. However, the authors indicate it is likely not as the E. coli paradigm LexA global repressor since it functions as an activator of other DNA damage response genes (Aranda et al., 2013).

In the present study, we used single-cell analyses to investigate the potential for a unique mode of regulation of several DNA damage-inducible genes in A. baumannii in response to DNA damaging treatment. Using green fluorescent protein (GFP) fused to DNA damageinducible gene promoters, we studied the induction of DNA damage response genes in individual cells in response to treatment with the antibiotic ciprofloxacin, which inhibits 
DNA gyrase and causes DNA double strand breaks (Chen et al., 1996), as well as the alkylating agent, methyl methanesulfonate (MMS). Using this technique, we were able to detect a bimodal pattern of induction in response to DNA damage that could contribute to the rapid adaptability of A. baumannii. Additionally, we identified a palindromic regulatory motif upstream of the DNA damage response genes $u m u D C$ and $d d r R$, representing a potential binding site for regulator(s) involved in this response. We found that changes to the sequence of this conserved motif greatly reduced the bimodal induction of a selected umuDC operon, indicating its importance in vivo.

\section{Results}

\section{A. baumannii cells differentiate into phenotypic subpopulations in response to ciprofloxacin treatment}

Our previous work indicates that the DNA damage response in A. baumannii is likely different than the E. coli paradigm (Norton et al., 2013). Here, we sought to explore the response further by analyzing the induction of several DNA damage response genes using sensitive single cell analyses with flow cytometry. We constructed reporter strains in $A$. baumannii containing the putative promoter region of the gene of interest fused to green fluorescent protein (GFP) at the natural chromosomal locus (Fig. S1) for recA (A1S_1962, Recombinase A), $\operatorname{din} B$ (A1S_0186, DNA Polymerase IV), итиDC (A1S_0636-0637, DNA Polymerase V), $u v r A$ (A1S_3295, UvrABC endonuclease), and a non-DNA damage inducible gene control, trpB (A1S_1692, Tryptophan synthase subunit B). Downstream of the GFP gene, the putative promoter region is duplicated leading into the wild-type gene on the chromosome, thus avoiding any disruption of the natural promoter and gene.

The reporter strains were untreated or treated with varying concentrations of ciprofloxacin (cip) at the beginning of exponential growth for 3 hours. Treatment levels were calculated based on the minimum inhibitory concentration (MIC) of cip in A. baumannii $\left(0.6 \mu \mathrm{g} \mathrm{mL}^{-1}\right)$, with each strain experiencing treatment ranging from sub-inhibitory to inhibitory $(0.3 \times, 1 \times$, $3 \times$ and $10 \times$ the MIC). Strains were analyzed for gene induction (i.e. fluorescent levels) directly before treatment $(T=0)$, at 90 minutes $(T=90)$, and after 180 minutes $(T=180)$ of treatment. The end-point was selected based on whole population survival curves in response to 10× the MIC cip in A. baumannii and E. coli (Fig. S2).

At $\mathrm{T}=0$, reporter strains for $\operatorname{rec} A, \operatorname{din} B, u m u D C, u v r A$ and $\operatorname{trp} B$ were largely unimodal and non-fluorescent for all treatment conditions, indicating no induction of the genes (Fig. 1). Over the 180-minute time-course, and in response to varying levels of cip, the $\operatorname{rec} A, \operatorname{din} B$, $u m u D C$ and $u v r A$ reporter strains followed a similar trend of differentiation into two subpopulations, both dim and bright. Generally, increasing treatment time and increasing cip concentration led to a higher proportion of bright cells and a decreasing proportion of dim cells, though some genes were more highly induced under lower concentrations of cip, such as $u m u D C$ and $u v r A$. The reporter strain for $\operatorname{trp} B$ was not induced by any concentration of cip and remained largely dim throughout the time course (Fig. 1). Uniform, whole population fluorescence was observed for this strain however, after nutrient starvation on Nematode Growth Medium (NGM) plates using microscopy, indicating that the $\operatorname{trp} B$ fusion is indeed functional (Fig. S3). 
We next compared this mode of induction in response to DNA damaging treatment to that of a comparable E. coli gene. Though the induction of DNA damage response genes has been explored extensively in E. coli (Anderson \& Kowalczykowski, 1998, Fijalkowska et al., 1997, Sutton et al., 2000, Pennington \& Rosenberg, 2007), we performed the same singlecell analysis described above on an E. coli $\operatorname{din} B$ (b0231) reporter strain containing a plasmid-borne promoter-GFP fusion to compare it to A. baumannii. The E. coli dinB reporter strain was treated with the same range of cip concentrations, relative to its own MIC $\left(0.01 \mu \mathrm{g} \mathrm{mL}^{-1}\right)$. When analyzed using flow cytometry at $\mathrm{T}=0$, the $E c \operatorname{din} B$ reporter showed one largely dim population under all treatment conditions (Fig. 2A), much as in the $A$. baumannii reporters. However, with increasing time and increasing cip concentration, the $E c$ $\operatorname{din} B$ reporter strain shifted into the fluorescent range, showing a unimodal distribution, compared to the bimodal shift seen in A. baumannii. This unimodal shift in $E$. coli in response to DNA damaging agents agrees with data shown by Pennington, et al. in 2007, where the addition of a DNA damaging agent creates a unimodal induction of DNA damage response genes (Pennington \& Rosenberg, 2007).

To ensure that the $E$. coli $\operatorname{din} B$ fusion was not affected by the use of a plasmid carrier, we also constructed an $E$. coli $\operatorname{din} B$ protein fusion to GFP, expressed from the chromosome. We used the chromosomal protein fusion rather than the chromosomal promoter fusion because the promoter fusion was not stable in E. coli for this gene. This chromosomal protein fusion strain was untreated or treated with $10 \times$ the MIC cip for 240 minutes and analyzed by flow cytometry. As with the plasmid-borne reporter, the $\operatorname{din} B$ protein-GFP strain showed a unimodal distribution. Without treatment, a single, wide peak formed in the dim range (Fig. $2 \mathrm{~B})$. With treatment, again a single peak formed. This peak was more tightly composed and shifted into the fluorescent range (Fig. 2B).

Finally, to further ensure that the bimodal induction seen in A. baumannii was different than the induction of the DNA damage response in E. coli regardless of the location of the fusion, we analyzed induction of a different $E$. coli DNA damage induced gene, sulA, with a promoter fusion expressed both from the chromosome and from a plasmid. As before, these strains were untreated or treated with 10x the MIC cip for 180 minutes before analysis. When the fusion was expressed both from the chromosome and from a plasmid, we saw a unimodal distribution of cells. The single peak was in the dim range for the untreated cells and shifted into the bright range for the treated cells (Fig. 2C). Taken together, these data suggest that whether expressed from a plasmid, or the chromosome, E. coli reporters for DNA damage genes show one main population of cells in response to damage, while $A$. baumannii forms two subpopulations.

We next wanted to determine if subpopulation formation in A. baumannii was resulting from genetic changes that could be passed to future generations.

\section{Bimodal response to ciprofloxacin treatment is not heritable}

To attribute subpopulation formation in A. baumannii to a genotypic or phenotypic change, we determined if the characteristics of each subpopulation were passed to future generations. We hypothesized that a genetic change or mutation would persist in future generations, causing dim-sorted cells to all remain dim and bright-sorted cells to all become bright upon 
recurrent challenge. Conversely, should the differentiation be caused by a phenotypic change, both the dim and bright subpopulations should again be able to generate two subpopulations upon treatment. We treated the A. baumannii dinB, uтuDC and $u v r A$ reporter strains with $10 \times$ MIC cip for three hours, as before. These strains were then sorted by fluorescence into dim and bright subpopulations (Fig. 3A). Each subpopulation was then inoculated into fresh medium and recovered for 20 hours. The recovered subpopulations for each reporter were then treated with a second round of $10 \times$ MIC cip for 3 hours, and analyzed by flow cytometry directly before and after treatment. After the initial overnight recovery, both subpopulations had returned to a unimodal, dim state (Fig. S4). After 3 hours of cip treatment, both bright and dim subpopulations again differentiated into two subpopulations, bright and dim (Fig. 3B). This result thus established the subpopulation formation was not heritable to future generations and was reversible upon removal of cip, allowing each subpopulation to differentiate to bright and dim cells.

We then sought to determine if the bimodal response to DNA damage was caused only by treatment with cip or if it resulted from other types of damaging treatment as well.

\section{A. baumannii response to methyl methanesulfonate treatment varies depending on gene analyzed}

To determine if the differentiation into subpopulations was caused exclusively by cip treatment, or if it was a more general response to DNA damage, we treated several of the $A b$ promoter fusion strains ( $A b \operatorname{rec} A, A b \operatorname{din} B, A b u m u D C, A b u v r A$ and $A b \operatorname{trp} B$ ) with the alkylating agent, methyl methanesulfonate (MMS) and analyzed fluorescence.

Reporter strains were treated with1x the MIC MMS at the beginning of exponential growth for 60 minutes and then analyzed by flow cytometry. Interestingly, the population dynamics in response to MMS varied based on the gene analyzed. The $A b \operatorname{din} B$ reporter strain formed two main subpopulations, bright and $\operatorname{dim}$ (Fig. 4). The $A b u m u D C$ reporter strain also formed two populations, though the induction levels were higher than those for $\operatorname{din} B$. $u m u D C$ was more highly induced than any other gene analyzed, suggesting that $u m u D C$ is highly responsive to MMS treatment (Fig. 4). The Ab recA and $u v r A$ reporter strains formed one main population, however, these populations were found closer to the dim range, suggesting $r e c A$ and $u v r A$ may not be highly induced by MMS (Fig. 4). Lastly, the $A b \operatorname{trp} B$ reporter strain was not fluorescent in response to MMS treatment. This strain formed one main population of dim cells (Fig. 4).

As little is known about the factors causing this unique type of regulation of the DNA damage response genes in A. baumannii, we next took a bioinformatics approach to identify possible regulatory motifs within the putative promoter regions of the genes analyzed in this study.

\section{Strong palindromic, regulatory motif found upstream of umuD, umuC and $d d r R$ genes}

Initially, to search for a putative regulatory motif, the intergenic regions between $d d r R$ (A1S_1388) and $и т и D$ (A1S_1389) were collected from six complete and nine partial genomic sequences of Acinetobacter spp. from NCBI Genbank. A conserved palindromic 
motif was identified between the $d d r R$ gene and $u m u D$ gene in eleven genomes (six complete, five partially sequenced) (Fig. 5A). A whole-genome search with this motif identified additional motifs, upstream of the $u m u D C$ operons, the single $u m u D$ and single ити $C$ genes and $d d r R$ in all six complete genomes (Table 1). In the strain used predominantly in this study, A. baumannii ATCC 17978, the palindromic motif was found upstream of итиDC (A1S_1174-1173), итиDC (A1S_0636-0637), итиC (A1S_2008), $u m u D$ (A1S_1389), итиC (A1S_2015) and $d d r R$.

To ascertain the in vivo importance of this motif, we created a reporter GFP strain for the итиDC (A1S_0636-0637) gene at the chromosomal locus as before, but altered the regulatory motif in the promoter region by changing 7 of the most highly conserved nucleotides (Fig. 5B). This reporter strain is isogenic to the $u m u D C$ reporter strain (umuDC pr-GFP) used in Fig. 1, with the exception of the altered motif.

The altered motif strain (umuDC pr*-GFP) was then either left untreated or treated with $10 \times$ MIC cip for 180 minutes as before, and analyzed by FACS at 0,90 and 180 minutes. The untreated strain remained largely unimodal and dim throughout the time course, showing no induction of the gene (Fig. 5C, left), much as in umuDC pr-GFP with the wild-type motif.

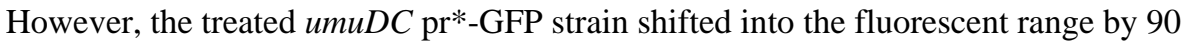
minutes and remained fluorescent at the 180-minute time point. The umuDC $\mathrm{pr}^{*}$-GFP reporter strain was almost completely lacking a dim subpopulation (Fig. 5C, right), dramatically contrasting what was seen under the same conditions in the isogenic umuDC pr-GFP strain (Fig. 1), indicating a role for the conserved motif in subpopulation formation.

To explore the response of this mutant reporter to other treatments, the $u m u D C \mathrm{pr}^{*}$-GFP and uтиDC pr-GFP strains were next untreated or treated at exponential phase with $0.3 \times$ and $1 \times$ the MIC MMS for 60 minutes followed by flow cytometry analysis. The untreated $u m u D C$ pr*-GFP and umuDC pr-GFP strains each formed one peak. Both strains showed some background fluorescence, though the reporter for the wild-type promoter was shifted farther into the fluorescent range (Fig. 5D). Upon treatment with $0.3 \times$ and $1 \times$ the MIC MMS, both strains remained largely unimodal and shifted to the fluorescent range above their background fluorescence. Interestingly, the $и т и D C \mathrm{pr}^{*}$-GFP strain remained less induced than the strain with the wild-type reporter at both $0.3 \times$ and $1 \times$ MIC treatment (Fig. 5D).

Lastly, to identify possible survival advantages, we then explored the killing effect of cip on the bright and dim subpopulations individually.

\section{Dim subpopulation has survival advantage over bright subpopulation in ciprofloxacin}

To determine survival of each subpopulation in cip, we sorted A. baumannii cells into bright and dim subpopulations after 3 hours of $10 \times$ MIC cip treatment, using the $и т и D C$ reporter. We then plated these cells and determined the percent survival for each subpopulation compared to the total number of cells sorted (250,000 cells per subpopulation). We also analyzed the survival of bright-sorted cells containing the $u m u D C \mathrm{pr}^{*}$-GFP reporter. Through six independent trials, we found the dim cells, on average, to survive 10 times better than the sorted bright cells from both the wild-type and promoter mutant reporters in 10× MIC cip (Fig. 6). 


\section{Discussion}

We have examined the induction of several DNA damage response genes by fusing the putative promoter region of each gene to GFP at the natural chromosomal locus and observing fluorescence in response to DNA damaging treatment using flow cytometry. In this way, we have found A. baumannii to foster two subpopulations in response to DNA damage caused by ciprofloxacin (Fig. 1). Upon treatment, $\operatorname{din} B, u m u D C$, $u v r A$ and recA are induced in one subpopulation, while another shows no induction. We have found that the differentiation into bright and dim subpopulations is not heritable to future generations beyond 20 hours (Fig. 3). We also found subpopulation formation in response to MMS treatment, though the extent of this varied based on the gene analyzed (Fig. 4). To our knowledge, bimodal induction in response to a DNA damaging agent has not been shown before. The wealth of knowledge pertaining to DNA damage response systems centers mainly on E. coli, where upon DNA damaging treatment, genes are expressed unimodally, with genes with lower promoter affinity for the repressor being transcribed first (Friedberg et al., 2006, Courcelle et al., 2001). Previously, in the absence of DNA damaging treatment, population heterogeneity has been observed in expression of DNA damage response genes in $E$. coli, in strains mutated for genes such as priA, which is involved in replication fork restart, or polA, which codes for DNA Polymerase I (McCool et al., 2004). Spontaneous, heterogeneous DNA damage response has also been seen in E. coli, again in the absence of treatment, by Pennington, et al. (Pennington \& Rosenberg, 2007), however, when treated with UV light, E. coli cells were induced unimodally.

Research has previously indicated that the DNA damage response in Acinetobacter spp., including A. baumannii, differs from the well-described paradigm found in E. coli. Rauch et al. describe the induction of RecA in A. baylyi to occur independently of the functional protein itself (Rauch et al., 1996). This contradicts the system in E. coli where recA induction is reliant on functional RecA, to cleave the LexA repressor (Little et al., 1981). Recently, we have shown similar findings in A. baumannii, demonstrating a DNA damagedependent increase in transcription of recA in the absence of the functional protein itself (Norton et al., 2013). These observations indicate that the DNA damage response system in Acinetobacter spp. may operate independently of a repressor. Indeed, Aranda et al. recently described a regulatory role for the A1S_1389 gene product (Aranda et al., 2013). Insertional inactivation of this gene on the A. baumannii 17978 strain chromosome resulted in decreased expression of other genes known to be part of the DNA damage response, suggesting it functions as an activator. Taking all of these result together, it is clear that a different regulatory mechanism is likely controlling the DNA damage response in $A$. baumannii and leading to the subpopulation formation we have observed.

Because bacteria divide symmetrically and grow as clonal populations, whole population analyses often assume all cells will respond identically; yet the differentiation into subpopulations, through phenotypic variation, has been shown to be prevalent in bacterial species, rendering these types of studies unable to uncover the intricacies of some regulatory systems (Dubnau \& Losick, 2006, Smits et al., 2006). We have shown that the subpopulations are not due to genetic changes (Fig 3). However, because the recovery time after cip treatment and sorting is approximately 20 hours, and most of the bright cells are 
killed by the treatment, the recovered subpopulation could be the offspring of a small number of survivors, and perhaps not fully representative of the starting population. Alternatively, the changes might be explained by gene amplification. Gene amplification is a proven mechanism for evolution and acquisition of new gene product functions that includes the adaptation of genes acquired by horizontal gene transfer (Elliott et al., 2013), and antibiotic resistance (Elliott et al., 2013, Seaton et al., 2012, Reams \& Neidle, 2004, Reams $\&$ Neidle, 2003). Such changes are usually unstable and difficult to detect (Andersson \& Hughes, 2009), however they allow bacteria to increase the chance of acquiring mutations (Bergthorsson et al., 2007, Nasvall et al., 2012, Andersson \& Hughes, 2009).

A possible explanation for the regulation of the DNA damage response genes leading to subpopulation formation in A. baumannii is bistability. An example of bistability is the transcriptional regulation of the lac operon, in which cells within a clonal population show varying induction of this operonin response to the same stimuli (Novick \& Weiner, 1957, Monod \& Jacob, 1961, Ozbudak et al., 2004). In the case of A. baumannii however, further research is needed to fully understand the mechanisms underlying the formation of subpopulations and to determine if this system is bistable.

A. baumannii is a highly adaptable pathogen, able to survive desiccation and colonize human hosts (Gaddy \& Actis, 2009, Giannouli et al., 2013, Stacy et al., 2012). In response to DNA damage, A. baumannii could be using bimodal induction of DNA damage response genes within the population as one option to increase odds of survival in ever-changing environments. Similarly, in Saccharomyces cerevisiae, increased phenotypic switching capabilities have been shown to give growth advantages (Acar et al., 2008, Bishop et al., 2007). Additionally, entry into sporulation in Bacillus subtilis has been identified as a bethedging strategy, in which a subpopulation of cells enter sporulation to give a reproductive advantage to the growing subpopulation (Veening et al., 2008). We were able to detect an approximate 10-fold difference in survival of dim cells over bright cells in ciprofloxacin (Fig. 6), showing an advantage for differentiation into subpopulations. In addition to their survival advantage, the dim cells would also likely be better suited to conjugate with other species, as DNA damage genes are often suppressed by conjugative elements (Bagdasarian et al., 1986, Golub et al., 1988). Dim cells could therefore adapt through DNA exchange within the species and with other species. It is possible that the dim cells possess a survival advantage over the bright cells because the multiple copies of $u m u D$ and $u m u C$ create higher intercellular concentrations of the error-prone DNA polymerase $\mathrm{V}$ upon induction, creating perhaps unusually high levels of mutagenesis. It is known that high intracellular levels of the $u m u D C$ or $\operatorname{din} B$ genes products are lethal to $E$. coli. It is also known that translesion synthesis proficient Salmonella strains are prone to spontaneous deletions (Koskiniemi \& Andersson, 2009), which again can prove lethal. All of these reasons might cause us to observe fewer surviving bright cells. However, cells belonging to the bright subpopulation, with such heightened expression of DNA Pol V would be more likely to accumulate base pair substitutions (Napolitano et al., 2000, Watanabe-Akanuma et al., 1997) that might occasionally prove useful for acquiring resistance to other antibiotics, such as rifampicin (Giannouli et al., 2012), or give an evolutionary advantage. In those cases, the one mutated cell could then propagate and replenish the population. By fostering both subpopulations in 
response to DNA damage, A. baumannii creates two subsets of cells, each employing very different strategies to increase chances of survival in a changing environment.

In efforts to shed light on the regulatory circuitry behind the DNA damage response system in A. baumannii, we identified a palindromic regulatory motif, upstream of the DNA damage response $d d r R$ and $u m u D C$ genes (Fig. 5A). This motif is conserved throughout other A. baumannii strains, as well as different Acinetobacter species. Upon altering the nucleotide sequence of the motif in the $u m u D C$ reporter strain, we saw a change in the induction profile of $u m u D C$ from bimodal induction with the motif intact, to nearly unimodal induction in its absence (Fig. 5C). We also saw diminished bright fluorescence (i.e. gene induction levels) compared to the wild-type motif in response to MMS treatment (Fig. 5D). These changes show the importance of the motif in the regulation of the umuDC genes in vivo and indicate that the motif likely represents a binding site for the regulator responsible for the bimodal phenotype.

To our knowledge, the bimodal expression of DNA damage response genes upon treatment with a DNA damaging agent has not been observed in other well-described systems, such as in E. coli (Friedberg et al., 2006, Radman, 1975). This unusual type of regulation gives a survival advantage to the uninduced cells and could be responsible for quick adaptability in A. baumannii, ultimately promoting survival in changing environments. Further investigation into the network and possible regulator(s) involved in this system will lead to a more complete picture, giving insights into its effects on pathogenicity and adaptability. Heterogeneous populations have been seen in many types of bacteria and it is likely that bimodal regulation happens much more readily than is known, since many assays operate at the population level. With more focused analyses of single cells, bacterial survival strategies can be dissected more finely, giving forth results that are more pertinent to natural systems.

\section{Experimental Procedures}

\section{Bacterial strains and culturing conditions}

Strains and plasmid used are listed in Table 2. Luria-Bertani (LB) medium (Becton Dickinson, Sparks, MD) was used for the growth of all strains. Cultures were incubated at $37^{\circ} \mathrm{C}$ and $225 \mathrm{rpm}$. Kanamycin (kan; $35 \mu \mathrm{g} \mathrm{mL}{ }^{-1}$; EMD Biosciences, Inc., La Jolla, CA), chloramphenicol (cam; E. coli $\mathrm{MIC}=20 \mu \mathrm{gmL}^{-1}$ : Sigma-Aldrich, St. Louis, MO) and ciprofloxacin (cip; A. baumannii $\mathrm{MIC}=0.6 \mu \mathrm{gmL}^{-1}$, E. coli $\mathrm{MIC}=0.01 \mu \mathrm{gmL}^{-1}$; SigmaAldrich) and methyl methanesulfonate (MMS; A. baumannii MIC $=25 \mathrm{mM}$; Sigma-Aldrich) were added to the medium as indicated in the text.

\section{A. baumannii reporter strain construction}

The A. baumannii $\operatorname{din} B, u m u D, u v r A, \operatorname{rec} A$ and $\operatorname{trp} B$ putative promoter regions (Supplementary Table 1) were amplified using polymerase chain reaction (PCR) with the oligonucleotides listed in Table 3. The forward and reverse oligonucleotides included the restriction sites XhoI and BamHI, respectively, for use in the downstream construction of recombinant plasmids. The PCR amplicons were cleaned up using a QIAquick PCR Purification Kit (Qiagen, Valencia, CA) and digested with the appropriate enzymes in a 
double digest as suggested by the manufacturer (New England Biolabs, Ipswich, MA). The plasmid, pUA66 (Zaslaver et al., 2006), was also digested in the same manner. Both digests were separated using a $1 \%$ agarose gel and extracted using a QIAquick Gel Purification Kit (Qiagen). The insert and vector were then ligated using T4 ligase (Promega, Madison, WI) at $4{ }^{\circ} \mathrm{C}$ overnight. Electrocompetent $A$. baumannii cells were prepared as follows. Cultures were grown in $30 \mathrm{~mL} \mathrm{LB}$ at $37{ }^{\circ} \mathrm{C}$ to exponential phase and made electrocompetent by washing three times with ice-cold $10 \%$ glycerol and then concentrating 200-fold. $150 \mathrm{ng}$ DNA was introduced into $50 \mu \mathrm{L}$ cells by electroporation. Transformants were plated on LB agar supplemented with kan. Colonies that resulted were suspected to contain the full plasmid on the chromosome as a result of a single crossover event at the homologous promoter region, as the pUA66 plasmid does not replicate in A. baumannii (Fig. S1). Expected chromosomal insertions were confirmed by sequencing using the internal and flanking oligonucleotides listed in Table 3.

\section{E. coli DinB protein-GFP reporter construction}

The $E$. coli $\operatorname{din} B-G F P$ fusion gene was originally generated in pCA24N-dinB (Kitagawa et al., 2005). Site-directed mutagenesis using the GeneTailor ${ }^{\mathrm{TM}}$ kit was performed in accordance with manufacturer's instructions using oligonucleotides listed in Table 3 to generate the A206K mutation in the GFP gene. This mutation assures the monomeric state of GFP (von Stetten et al., 2012). The dinB-GFP (A206K) and $c a m^{\mathrm{R}}$ from pKD3 (Datsenko $\&$ Wanner, 2000) amplicons were generated and fused by overlap extension PCR using oligonucleotides listed in Table 3. PCR products were separated by $1 \%$ agarose gel and extracted using a QIAquick Gel Purification Kit (Qiagen). The resulting DNA fragment was recombined onto the chromosome by SOE-LRED (Benson et al., 2011). Transformants were selected for on LB agar supplemented with cam. The successful integration of the $\operatorname{din} B-G F P$ allele onto the chromosome was confirmed by PCR and DNA sequencing.

\section{Flow cytometry analyses}

All A. baumannii strains were grown overnight with kan. Overnight cultures were subcultured 1:1000 into fresh medium supplemented with kan. Cultures were grown to exponential phase (approximately 2.5 hours), and then cip or MMS were added to the media, or cells were left untreated. Cultures were monitored for 180 minutes with FACS analysis at 0, 90 and 180 minutes (cip) or 60 minutes with FACS analysis at endpoint (MMS). For FACS analysis, cultures were diluted 1:100 into 1\% sodium chloride solution (Thermo Fisher Scientific, Waltham, MA) and 1,000,000 cells were analyzed for fluorescence per sample using BD FACSAria II sorter (BD Biosciences, San Jose, CA). Data were analyzed using FlowJo software (Version 9.6.3).

For E. coli reporter strains, an overnight culture was subcultured 1:100 and grown for 3 hours twice a day, and subcultured 1:1000 overnight. This set of outgrowths was repeated twice. Cam was added to the E. coli $\operatorname{din} B-G F P$ cultures grown to exponential phase at $30^{\circ} \mathrm{C}$, and either cip was added to the media or cells were left untreated. At 240 minutes after adding cip, FACS analysis was performed on $1 \times 10^{6}$ cells for fluorescence as above. The $E$. coli chromosomal and plasmid borne sulA-GFP (Benson et al., 2011) were grown with no 
antibiotic or kan, respectively. After cultures reached exponential phase, these were treated with cip and analyzed by fluorescence at 180 minutes as above.

\section{Fluorescence automated cell sorting and re-treatment}

Strains were prepared for flow cytometry analyses as described above. After cip treatment, 10,000 cells from each strain were analyzed for fluorescence. Each strain was then sorted into a dim $\left(10^{1}-10^{3}\right.$ FITC-H units) and bright $\left(10^{3}-10^{5}\right.$ FITC-H units) subpopulation, each consisting of 200,000 cells. Duplicate sorted subpopulations were re-analyzed using FACS to ensure proper sorting of dim and bright cells. The sorted cells were inoculated into $30 \mathrm{ml}$ LB supplemented with kan and grown 20 hours. After 20 hours, each sorted subpopulation was treated in exponential phase with $10 \times$ MIC cip and flow cytometry analyses again as described above. Cultures were analyzed using FACS at 0, 60, 120 and 180 minutes treatment.

\section{Bioinformatics analyses}

Complete genome sequences of six Acinetobacter species uploaded from NCBI GenBank database (Benson et al., 2013) were analyzed in this study: Acinetobacter baumannii AB0057 (NC_011586), Acinetobacter baumannii ATCC 17978 (NC_009085), Acinetobacter baumannii MDR-ZJ06 (NC_017171), Acinetobacter baylyi ADP1 (NC_005966), Acinetobacter calcoaceticus PHEA-2 (NC_016603) and Acinetobacter oleivorans DR1 (NC_014259).

Motif detection was performed using Discover Profile tool implemented in RegPredict web server (Novichkov et al., 2010). For discovery of a putative regulatory motif upstream of $u m u D C$ operons, intergenic regions between $d d r R$ and $u m u D$ genes were collected from all studied genomes. Nine additional $d d r R$-umuD intergenic regions from other Acinetobacter species were added to the training set to achieve higher specificity of motif discovery. The search for the palindromic motif was conducted with default parameters except motif size range, which was 16-28 basepairs (bp).

The motif identified was initially validated by whole-genome search in A. baumannii AB0057 and A. baylyi ADP1 available in RegPredict using Run Profile tool and then detailed regulon reconstruction was done in all six genomes using GenomeExplorer package (Mironov et al., 2000). The search was performed in a range -250 through +50 bp with respect to the gene start, with a threshold for the search defined as a lowest score observed in the training set.

\section{Construction and FACS analysis of umuDC altered motif pr-GFP strain}

A double-stranded DNA fragment consisting of 548 basepairs upstream of the A. baumannii umuDC(A1S_0636-0637) start codon flanked by an Xhol restriction site at the $5^{\prime}$ end and the first 30 basepairs of the GFP gene at the $3^{\prime}$ end was manufactured by Life Technologies (GeneArt ${ }^{\circledR}$ Strings ${ }^{\mathrm{TM}}$ DNA fragments, Grand Island, NY). The predicted regulatory motif in this fragment was altered as shown in Fig. 5B. This fragment was joined to $g f p$ using splicing overlap extension (SOE) PCR with the umuDC upstream and GFP gene R primers listed in Table 3. Next, the kanamycin gene from the pUA66 plasmid and the umuDC gene 
were amplified using Kan $\mathrm{F}$ and $\mathrm{Kan} \mathrm{R}$ and $u m u D C$ gene $\mathrm{F}$ and $u m u D C$ gene $\mathrm{R}$, respectively (Table 3). The uтиDC gene F primer contained homology to the kan F primer (underlined) to aid in SOE PCR. These two fragments were then joined using SOE PCR with the primers Kan R and umuDC gene R (Table 3). The umuDC upstream - GFP fragment and kan $u m u D C$ gene fragment were then ligated separately into the pGEM Easy T-vector according to the manufacturer's instructions (Promega). The umuDC upstream - GFP T-vector was digested with XhoI to remove the insert and the kan - umuDC gene T-vector was linearized with SalI according to the manufacturer's instructions (NEB). The digests were separated using $1 \%$ agarose gel electrophoresis and extracted using a QIAquick Gel Purification Kit (Qiagen). The uтиDC - GFP insert was then ligated into the linearized T-Vector containing kan - uти $D C$ gene fragment. Recombinant plasmids were introduced into $E$. coli cells by transformation and checked for correct orientation (upstream umuDC-GFP - kan - umuDC gene). Plasmids containing the desired inserts were then introduced into A. baumannii cells by transformation where a double cross-over event allowed the upstream uтиDC-GFP kan - umuDC gene construct to move onto the chromosome as with the other promoter GFP reporters. Chromosomal insertions were checked by PCR. The umuDC pr*-GFP strain was then analyzed by flow cytometry after $10 \times$ MIC cip treatment at $\mathrm{T}=0$ and $\mathrm{T}=180$ minutes and $0.3 \times$ and $1 \times$ MIC MMS treatment at T=60 minutes, as detailed in Flow cytometry analyses section, above.

\section{Ciprofloxacin killing in sorted populations}

The $u m u D C$ reporter strain and $u m u D C$ pr*-GFP reporter strain were treated with $10 \times$ MIC cip during exponential phase as above and sorted into dim and bright subpopulations after 180 minutes, as described in fluorescence automated cell sorting and re-treatment section. 250,000 cells were sorted for each subpopulation. Liquid from cell sorting was deposited on LB agar plates supplemented with kan and plates were incubated at $37{ }^{\circ} \mathrm{C}$ overnight. Recovery was calculated as the percent of 250,000 cells that formed colonies on plates. Percent survival was calculated by first standardizing the fraction of surviving sorted dim or bright (or bright promoter mutant) with respect to sorted untreated cells. From such fractions the highest recovery was considered as $100 \%$. Data are comprised of 6 independent experiments and 5 independent experiments for the promoter mutant.

\section{Supplementary Material}

Refer to Web version on PubMed Central for supplementary material.

\section{Acknowledgments}

This work is dedicated to Gail P. Ferguson. The authors would like to acknowledge Tiziana M. Cafarelli for her assistance with flow cytometry. The authors declare no conflict of interest.

Financial Disclosure: This work was supported by the grant 1RO1GM088230-01A1 and its supplement from the National Institutes of Health (NIH) Institute of General Medicine to V.G. Godoy, and by the Office of Science, Office of Biological and Environmental Research, of the U.S. Department of Energy under contract DESC0004999 to A. Kazakov and P. Novichkov. The funders had no role in study design, data collection and analysis, decision to publish, or preparation of the manuscript. 


\section{References}

Acar M, Mettetal JT, van Oudenaarden A. Stochastic switching as a survival strategy in fluctuating environments. Nat Genet. 2008; 40:471-475. [PubMed: 18362885]

Adams MD, Chan ER, Molyneaux ND, Bonomo RA. Genomewide analysis of divergence of antibiotic resistance determinants in closely related isolates of Acinetobacter baumannii. Antimicrob Agents Chemother. 2010; 54:3569-3577. [PubMed: 20530228]

Anderson DG, Kowalczykowski SC. Reconstitution of an SOS response pathway: derepression of transcription in response to DNA breaks. Cell. 1998; 95:975-979. [PubMed: 9875851]

Andersson DI, Hughes D. Gene amplification and adaptive evolution in bacteria. Annu Rev Genet. 2009; 43:167-195. [PubMed: 19686082]

Aranda J, Poza M, Shingu-Vazquez M, Cortes P, Boyce JD, Adler B, Barbe J, Bou G. Identification of a DNA-damage-inducible regulon in Acinetobacter baumannii. J Bacteriol. 2013; 195:5577-5582. [PubMed: 24123815]

Bagdasarian M, Bailone A, Bagdasarian MM, Manning PA, Lurz R, Timmis KN, Devoret R. An inhibitor of SOS induction, specified by a plasmid locus in Escherichia coli. Proc Natl Acad Sci U S A. 1986; 83:5723-5726. [PubMed: 3526338]

Benson DA, Cavanaugh M, Clark K, Karsch-Mizrachi I, Lipman DJ, Ostell J, Sayers EW. GenBank. Nucleic Acids Res. 2013; 41:D36-42. [PubMed: 23193287]

Benson RW, Cafarelli TM, Godoy VG. SOE-LRed: A simple and time-efficient method to localize genes with point mutations onto the Escherichia coli chromosome. J Microbiol Methods. 2011A; 84:479-481. [PubMed: 21185880]

Benson RW, Norton MD, Lin I, Du Comb WS, Godoy VG. An active site aromatic triad in Escherichia coli DNA Pol IV coordinates cell survival and mutagenesis in different DNA damaging agents. PLoS One. 2011B; 6(5):e19944. [PubMed: 21614131]

Bergthorsson U, Andersson DI, Roth JR. Ohno's dilemma: evolution of new genes under continuous selection. Proc Natl Acad Sci U S A. 2007; 104:17004-17009. [PubMed: 17942681]

Bishop AL, Rab FA, Sumner ER, Avery SV. Phenotypic heterogeneity can enhance rare-cell survival in 'stress-sensitive' yeast populations. Mol Microbiol. 2007; 63:507-520. [PubMed: 17176259]

Chen CR, Malik M, Snyder M, Drlica K. DNA gyrase and topoisomerase IV on the bacterial chromosome: quinolone-induced DNA cleavage. J Mol Biol. 1996; 258:627-637. [PubMed: 8636997]

Courcelle J, Khodursky A, Peter B, Brown PO, Hanawalt PC. Comparative gene expression profiles following UV exposure in wild-type and SOS-deficient Escherichia coli. Genetics. 2001; 158:4164. [PubMed: 11333217]

Datsenko KA, Wanner BL. One-step inactivation of chromosomal genes in Escherichia coli K-12 using PCR products. Proc Natl Acad Sci U S A. 2000; 97:6640-6645. [PubMed: 10829079]

Dijkshoorn L, Nemec A, Seifert H. An increasing threat in hospitals: multidrug-resistant Acinetobacter baumannii. Nat Rev Microbiol. 2007; 5:939-951. [PubMed: 18007677]

Doi Y, Husain S, Potoski BA, McCurry KR, Paterson DL. Extensively drug-resistant Acinetobacter baumannii. Emerg Infect Dis. 2009; 15:980-982. [PubMed: 19523312]

Dubnau D, Losick R. Bistability in bacteria. Mol Microbiol. 2006; 61:564-572. [PubMed: 16879639]

Elliott KT, Cuff LE, Neidle EL. Copy number change: evolving views on gene amplification. Future Microbiol. 2013; 8:887-899. [PubMed: 23841635]

Fijalkowska IJ, Dunn RL, Schaaper RM. Genetic requirements and mutational specificity of the Escherichia coli SOS mutator activity. J Bacteriol. 1997; 179:7435-7445. [PubMed: 9393709]

Friedberg, E.; Walker, GC.; Siede, W.; Wood, RD.; Schultz, R. DNA Repair and Mutagenesis. ASM Press; New York: 2006.

Friedman N, Vardi S, Ronen M, Alon U, Stavans J. Precise temporal modulation in the response of the SOS DNA repair network in individual bacteria. PLoS Biol. 2005; 3:e238. [PubMed: 15954802]

Gaddy JA, Actis LA. Regulation of Acinetobacter baumannii biofilm formation. Future microbiology. 2009; 4:273-278. [PubMed: 19327114] 
Giannouli M, Antunes LC, Marchetti V, Triassi M, Visca P, Zarrilli R. Virulence-related traits of epidemic Acinetobacter baumannii strains belonging to the international clonal lineages I-III and to the emerging genotypes ST25 and ST78. BMC infectious diseases. 2013; 13:282. [PubMed: 23786621]

Giannouli M, Di Popolo A, Durante-Mangoni E, Bernardo M, Cuccurullo S, Amato G, Tripodi MF, Triassi M, Utili R, Zarrilli R. Molecular epidemiology and mechanisms of rifampicin resistance in Acinetobacter baumannii isolates from Italy. Int J Antimicrob Agents. 2012; 39:58-63. [PubMed: 22055530]

Golub E, Bailone A, Devoret R. A gene encoding an SOS inhibitor is present in different conjugative plasmids. J Bacteriol. 1988; 170:4392-4394. [PubMed: 3045095]

Hare JM, Bradley JA, Lin CL, Elam TJ. Diverse responses to UV light exposure in Acinetobacter include the capacity for DNA damage-induced mutagenesis in the opportunistic pathogens Acinetobacter baumannii and Acinetobacter ursingii. Microbiology. 2012; 158:601-611. [PubMed: 22117008]

Hare JM, Perkins SN, Gregg-Jolly LA. A constitutively expressed, truncated $u m u D C$ operon regulates the recA-dependent DNA damage induction of a gene in Acinetobacter baylyi strain ADP1. Appl Environ Microbiol. 2006; 72:4036-4043. [PubMed: 16751513]

Hornsey M, Loman N, Wareham DW, Ellington MJ, Pallen MJ, Turton JF, Underwood A, Gaulton T, Thomas CP, Doumith M, Livermore DM, Woodford N. Whole-genome comparison of two Acinetobacter baumannii isolates from a single patient, where resistance developed during tigecycline therapy. J Antimicrob Chemother. 2011; 66:1499-1503. [PubMed: 21565804]

Hua X, Zhou H, Jiang Y, Feng Y, Chen Q, Ruan Z, Yu Y. Genome sequences of two multidrugresistant Acinetobacter baumannii strains isolated from a patient before and after treatment with tigecycline. J Bacteriol. 2012; 194:6979-6980. [PubMed: 23209232]

Jawad A, Seifert H, Snelling AM, Heritage J, Hawkey PM. Survival of Acinetobacter baumannii on dry surfaces: comparison of outbreak and sporadic isolates. J Clin Microbiol. 1998; 36:1938-1941. [PubMed: 9650940]

Kitagawa M, Ara T, Arifuzzaman M, Ioka-Nakamichi T, Inamoto E, Toyonaga H, Mori H. Complete set of ORF clones of Escherichia coli ASKA library (a complete set of E. coli K-12 ORF archive): unique resources for biological research. DNA Res. 2005; 12:291-299. [PubMed: 16769691]

Koskiniemi S, Andersson DI. Translesion DNA polymerases are required for spontaneous deletion formation in Salmonella typhimurium. Proc Natl Acad Sci U S A. 2009; 106:10248-10253. [PubMed: 19525399]

Little JW, Edmiston SH, Pacelli LZ, Mount DW. Cleavage of the Escherichia coli lexA protein by the recA protease. Proc Natl Acad Sci U S A. 1980; 77:3225-3229. [PubMed: 6447873]

Little JW, Mount DW, Yanisch-Perron CR. Purified lexA protein is a repressor of the recA and lexA genes. Proc Natl Acad Sci U S A. 1981; 78:4199-4203. [PubMed: 7027255]

McCool JD, Long E, Petrosino JF, Sandler HA, Rosenberg SM, Sandler SJ. Measurement of SOS expression in individual Escherichia coli $\mathrm{K}-12$ cells using fluorescence microscopy. Mol Microbiol. 2004; 53:1343-1357. [PubMed: 15387814]

Mironov AA, Vinokurova NP, Gel'fand MS. Software for analyzing bacterial genomes. Molekuliarnaia biologiia. 2000; 34:253-262. [PubMed: 10779952]

Monod J, Jacob F. Teleonomic mechanisms in cellular metabolism, growth, and differentiation. Cold Spring Harb Symp Quant Biol. 1961; 26:389-401. [PubMed: 14475415]

Mugnier PD, Poirel L, Naas T, Nordmann P. Worldwide dissemination of the blaOXA-23 carbapenemase gene of Acinetobacter baumannii. Emerg Infect Dis. 2010; 16:35-40. [PubMed: 20031040]

Munoz-Price LS, Weinstein RA. Acinetobacter infection. The New England journal of medicine. 2008; 358:1271-1281. [PubMed: 18354105]

Musa EK, Desai N, Casewell MW. The survival of Acinetobacter calcoaceticus inoculated on fingertips and on formica. J Hosp Infect. 1990; 15:219-227. [PubMed: 1971628]

Napolitano R, Janel-Bintz R, Wagner J, Fuchs RP. All three SOS-inducible DNA polymerases (Pol II, Pol IV and Pol V) are involved in induced mutagenesis. EMBO J. 2000; 19:6259-6265. [PubMed: 11080171] 
Nasvall J, Sun L, Roth JR, Andersson DI. Real-time evolution of new genes by innovation, amplification, and divergence. Science. 2012; 338:384-387. [PubMed: 23087246]

Norton MD, Spilkia AJ, Godoy VG. Antibiotic resistance acquired through a DNA damage-inducible response in Acinetobacter baumannii. J Bacteriol. 2013; 195:1335-1345. [PubMed: 23316046]

Novichkov PS, Rodionov DA, Stavrovskaya ED, Novichkova ES, Kazakov AE, Gelfand MS, Arkin AP, Mironov AA, Dubchak I. RegPredict: an integrated system for regulon inference in prokaryotes by comparative genomics approach. Nucleic Acids Res. 2010; 38:W299-307. [PubMed: 20542910]

Novick A, Weiner M. Enzyme Induction as an All-or-None Phenomenon. Proc Natl Acad Sci U S A. 1957; 43:553-566. [PubMed: 16590055]

Ozbudak EM, Thattai M, Lim HN, Shraiman BI, Van Oudenaarden A. Multistability in the lactose utilization network of Escherichia coli. Nature. 2004; 427:737-740. [PubMed: 14973486]

Park YK, Peck KR, Cheong HS, Chung DR, Song JH, Ko KS. Extreme drug resistance in Acinetobacter baumannii infections in intensive care units, South Korea. Emerg Infect Dis. 2009; 15:1325-1327. [PubMed: 19751609]

Peleg AY, Seifert H, Paterson DL. Acinetobacter baumannii: emergence of a successful pathogen. Clin Microbiol Rev. 2008; 21:538-582. [PubMed: 18625687]

Pennington JM, Rosenberg SM. Spontaneous DNA breakage in single living Escherichia coli cells. Nat Genet. 2007; 39:797-802. [PubMed: 17529976]

Radman M. SOS repair hypothesis: phenomenology of an inducible DNA repair which is accompanied by mutagenesis. Basic Life Sci. 1975; 5A:355-367. [PubMed: 1103845]

Rauch PJ, Palmen R, Burds AA, Gregg-Jolly LA, van der Zee JR, Hellingwerf KJ. The expression of the Acinetobacter calcoaceticus recA gene increases in response to DNA damage independently of RecA and of development of competence for natural transformation. Microbiology. 1996; 142(Pt 4):1025-1032. [PubMed: 8936328]

Reams AB, Neidle EL. Genome plasticity in Acinetobacter: new degradative capabilities acquired by the spontaneous amplification of large chromosomal segments. Mol Microbiol. 2003; 47:12911304. [PubMed: 12603735]

Reams AB, Neidle EL. Gene amplification involves site-specific short homology-independent illegitimate recombination in Acinetobacter sp. strain ADP1. J Mol Biol. 2004; 338:643-656. [PubMed: 15099734]

Robinson A, Brzoska AJ, Turner KM, Withers R, Harry EJ, Lewis PJ, Dixon NE. Essential biological processes of an emerging pathogen: DNA replication, transcription, and cell division in Acinetobacter spp. Microbiol Mol Biol Rev. 2010; 74:273-297. [PubMed: 20508250]

Seaton SC, Elliott KT, Cuff LE, Laniohan NS, Patel PR, Neidle EL. Genome-wide selection for increased copy number in Acinetobacter baylyi ADP1: locus and context-dependent variation in gene amplification. Mol Microbiol. 2012; 83:520-535. [PubMed: 22211470]

Smits WK, Kuipers OP, Veening JW. Phenotypic variation in bacteria: the role of feedback regulation. Nat Rev Microbiol. 2006; 4:259-271. [PubMed: 16541134]

Stacy DM, Welsh MA, Rather PN, Blackwell HE. Attenuation of quorum sensing in the pathogen Acinetobacter baumannii using non-native N-Acyl homoserine lactones. ACS chemical biology. 2012; 7:1719-1728. [PubMed: 22853441]

Sutton MD, Smith BT, Godoy VG, Walker GC. The SOS response: recent insights into umuDCdependent mutagenesis and DNA damage tolerance. Annu Rev Genet. 2000; 34:479-497. [PubMed: 11092836]

Ubeda C, Maiques E, Knecht E, Lasa I, Novick RP, Penades JR. Antibiotic-induced SOS response promotes horizontal dissemination of pathogenicity island-encoded virulence factors in staphylococci. Mol Microbiol. 2005; 56:836-844. [PubMed: 15819636]

Veening JW, Stewart EJ, Berngruber TW, Taddei F, Kuipers OP, Hamoen LW. Bet-hedging and epigenetic inheritance in bacterial cell development. Proc Natl Acad Sci U S A. 2008; 105:43934398. [PubMed: 18326026]

von Stetten D, Noirclerc-Savoye M, Goedhart J, Gadella TW Jr, Royant A. Structure of a fluorescent protein from Aequorea victoria bearing the obligate-monomer mutation A206K. Acta Crystallogr Sect F Struct Biol Cryst Commun. 2012; 68:878-882. 
Walker GC, Marsh L, Dodson L. Cellular responses to DNA damage. Environ Health Perspect. 1985; 62:115-117. [PubMed: 3910414]

Watanabe-Akanuma M, Woodgate R, Ohta T. Enhanced generation of A:T-->T:A transversions in a recA730 lexA51(Def) mutant of Escherichia coli. Mutat Res. 1997; 373:61-66. [PubMed: 9015154]

Zaslaver A, Bren A, Ronen M, Itzkovitz S, Kikoin I, Shavit S, Liebermeister W, Surette MG, Alon U. A comprehensive library of fluorescent transcriptional reporters for Escherichia coli. Nature methods. 2006; 3:623-628. [PubMed: 16862137] 


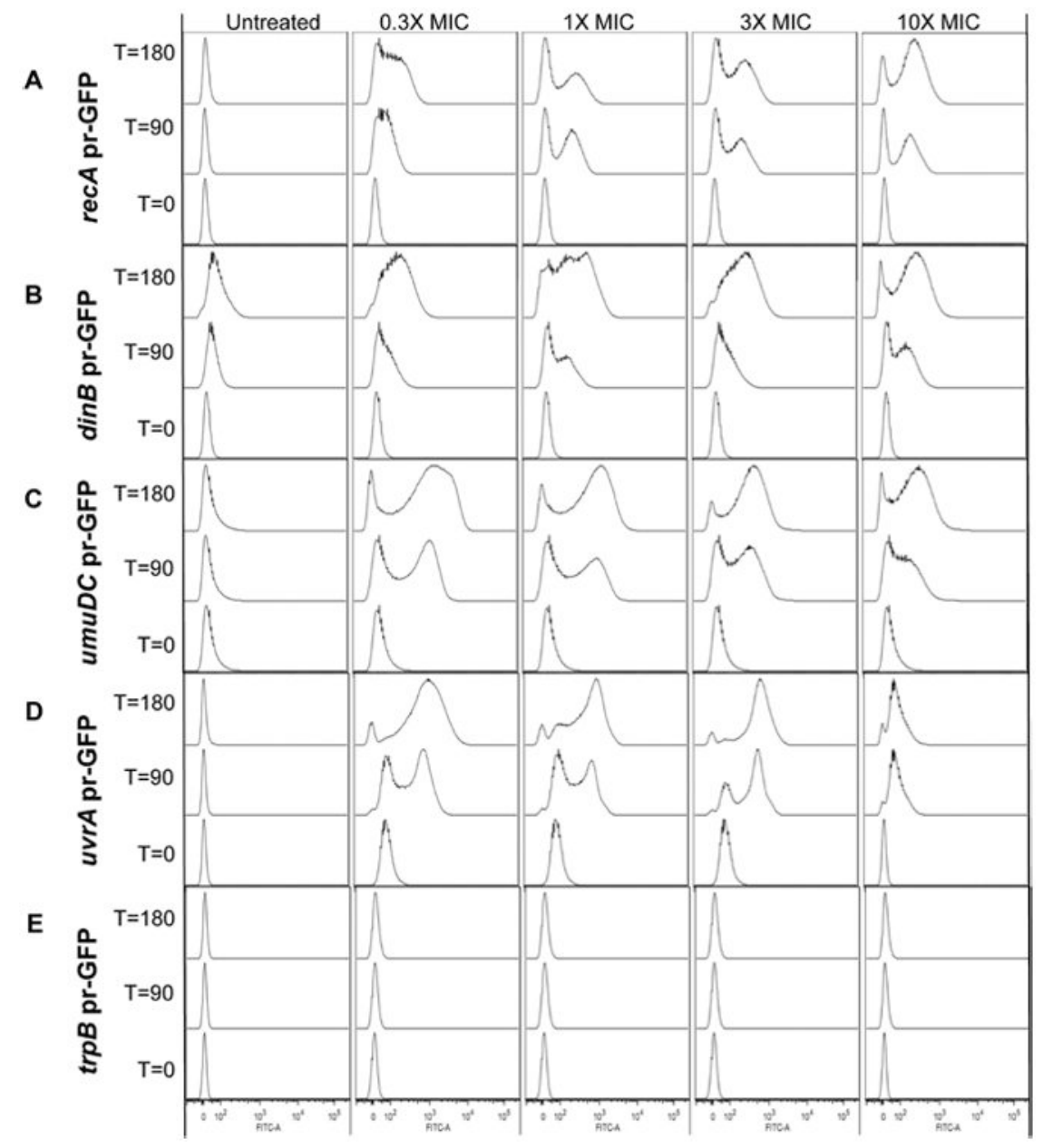

Figure 1. A. baumannii DNA damage response genes show bimodal induction after treatment with ciprofloxacin

Reporter strains were created in A. baumannii by fusing GFP to the upstream, putative promoter region of the gene of interest at the natural chromosomal locus. The promoter region was then duplicated leading into the wild-type gene. Green fluorescence is thus the readout of gene transcription. To analyze gene induction, each reporter was treated with a range of cip relative to the MIC $\left(0.61 \mu \mathrm{g} \mathrm{mL}^{-1}\right)$ during exponential phase and 1,000,000 cells were analyzed by FACS at T=0, 90 and 180 minutes. Histograms show cell number vs. fluorescent intensity (FITC-A) over the time course at each concentration. (A-D) All reporters show differentiation into dim and bright subpopulations. Generally, increasing cip concentration and time leads to a higher proportion of bright cells and a decreasing proportion of dim cells. Though some reporters (e.g. uтuDC) show higher induction levels at subinhibitory drug concentrations. (E) The $\operatorname{trp} B$ reporter remains largely unimodal and dim throughout treatment. 
A

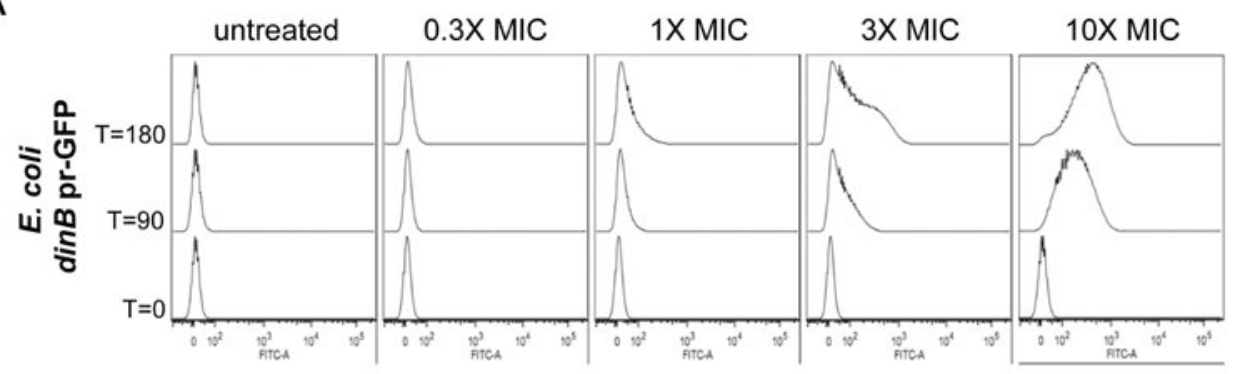

B

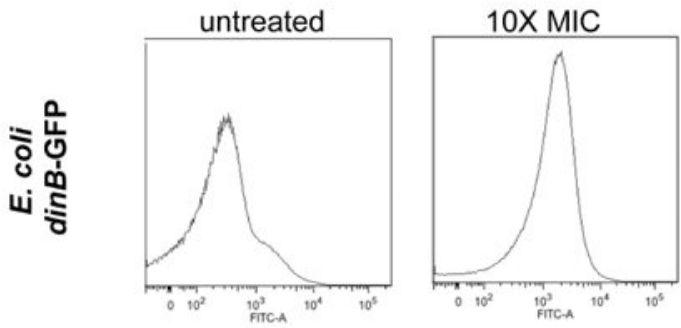

C
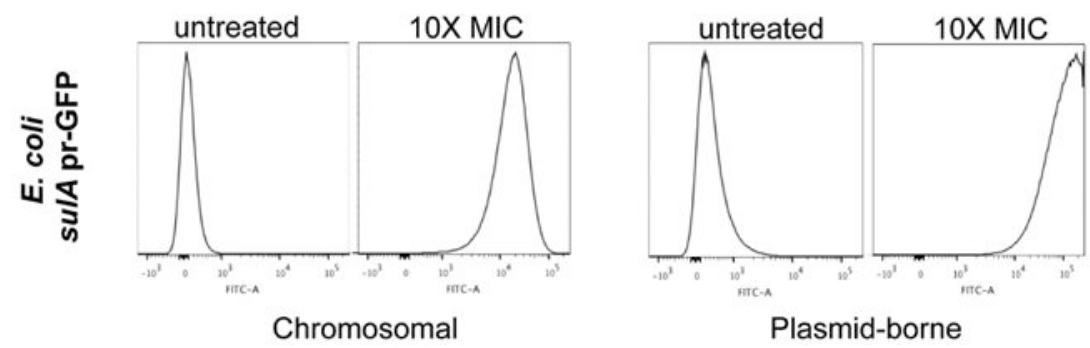

Figure 2. E. coli $\operatorname{din} B$ is induced unimodally by DNA damage

(A) A plasmid-borne reporter containing GFP fused to the upstream, putative promoter region of $\operatorname{din} B$ was used in $E$. coli. To analyze gene induction, cells were treated with a range of cip relative to the MIC $\left(0.01 \mu \mathrm{g} \mathrm{mL}^{-1}\right)$ during exponential phase and

1,000,000 cells were analyzed by FACS at T=0, 90 and 180 minutes. The $E$. coli dinB pr-GFP strain shows increasing fluorescence with increasing cip concentration and time, while remaining a unimodal population. (B-C) Cells were untreated or treated with 10× MIC cip and analyzed by FACS at 240 and 180 minutes, respectively. (B) A chromosomal reporter containing GFP fused to the $\operatorname{din} B$ protein was used in E. coli. Populations again remain unimodal with an increase in fluorescence in response to treatment. (C) Both a chromosomal and plasmid-borne reporter containing GFP fused to the upstream, putative promoter region of sulA were used in E. coli. Both reporters show unimodal populations, with an increase in fluorescence in response to treatment. Histograms show cell number vs. fluorescent intensity (FITC-A) over the time course at each concentration. 


$$
\text { A }
$$

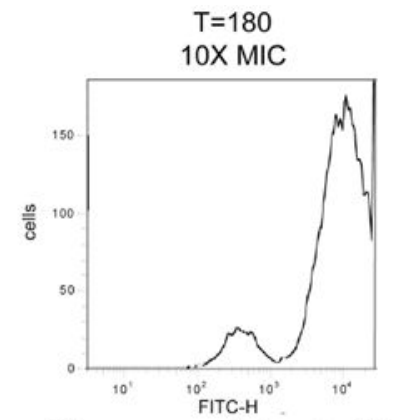

Fluorescence Automated Sorting

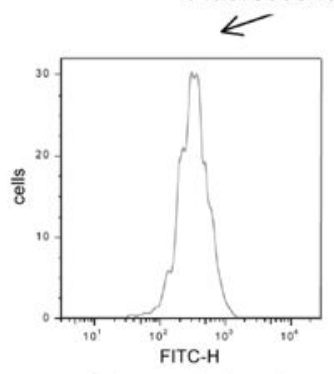

Subpopulation A

DIM

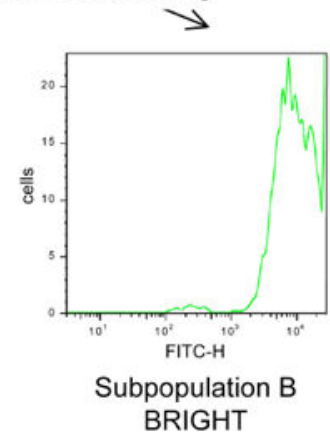

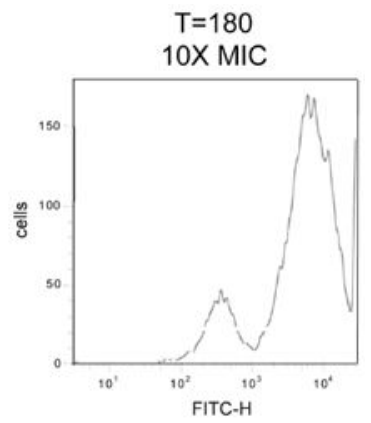

Subpopulation A

$\mathrm{T}=180$

10X MIC

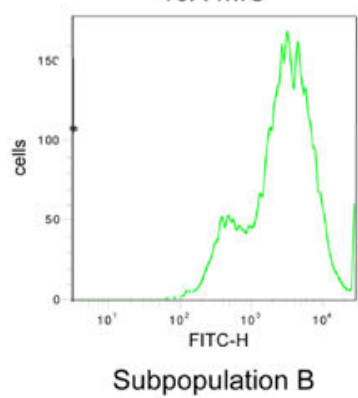

Figure 3. High or low induction levels are not heritable to future generations

(A) GFP transcriptional reporters for A. baumannii dinB, umuDC and $u v r A$ were treated with $10 \times \mathrm{MIC}\left(6.1 \mu \mathrm{g} \mathrm{mL}^{-1}\right)$ cip during exponential phase for 180 minutes. Each reporter was then sorted using FACS into a dim subpopulation and bright subpopulation, consisting of 100,000 cells each. Histograms show $A b$ umuDC reporter and are representative of all reporters tested. Top panel shows analysis of 10,000 cells after 3 hours cip treatment, immediately prior to sorting. Bottom panels show analysis 1,000 cells from sorted subpopulations, dim (Subpopulation A, left) and bright (Subpopulation B, right), to show sorting accuracy. (B) Sorted subpopulations were inoculated into fresh LB medium and grown for 20 hours. Each subpopulation was then subjected to cip treatment matching that of the previous day. FACS was used to analyze cultures after 3 hours of treatment. Again, representative histograms from $A b$ umuDC are shown. Both Subpopulation A (top) and Subpopulation B (bottom) differentiate into the two subpopulations upon repeated treatment. 


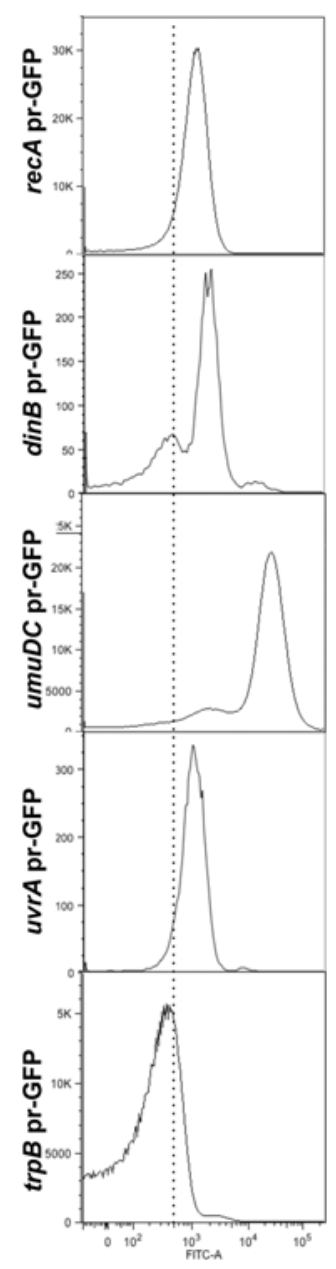

Figure 4. A. baumannii genes show variable induction after treatment with MMS

To analyze gene induction, each A. baumannii reporter was treated with $1 \times$ the MIC MMS (25 mM) during exponential phase and 1,000,000 cells were analyzed by FACS at T=60 minutes. Histograms show cell number vs. fluorescent intensity (FITC-A). The reporter strain for $\operatorname{din} B$ is most reminiscent of the cip treated strains, with two sharply defined subpopulations, one dim and one bright. The reporter strain for $u m u D$ again forms two subpopulations, though both are shifted further into the fluorescent range. The $u v r A$ and $r e c A$ reporters are unimodal and induced to a lower extent than $\operatorname{din} B$ or $u m u D$. The $\operatorname{trp} B$ reporter is also unimodal and found largely in the dim range. Basal level is found to the left of the broken line. 


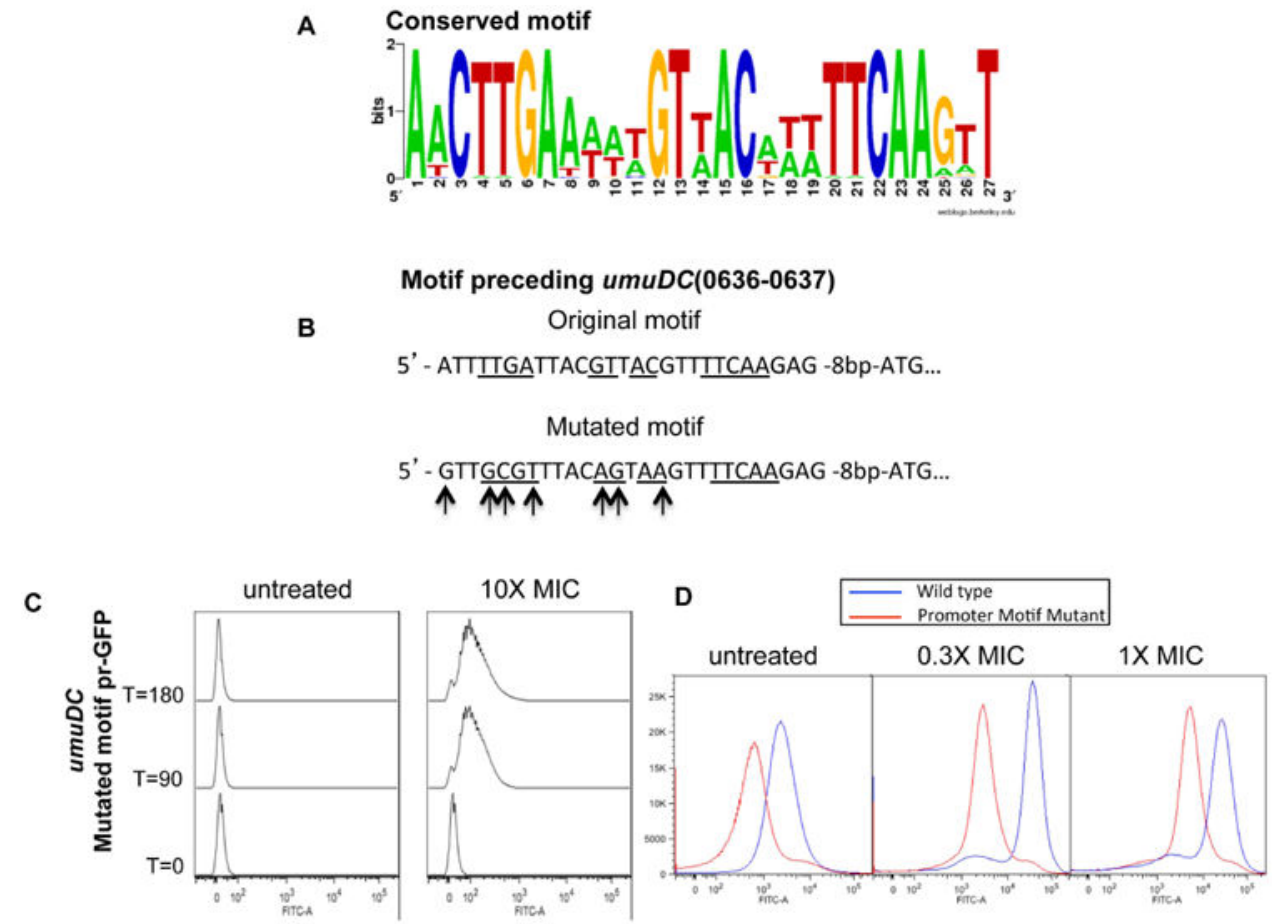

Figure 5. Palindromic regulatory motifs found upstream of umuD, umuC and $d d r R$ genes in Acinetobacter strains contribute to subpopulation formation

(A) Palindromic repeat motif identified upstream of $u m u D$, итиC and $d d r R$ genes in Acinetobacter species. Letter height indicates conservation level. (B) In vivo activity of the motif was determined by introducing changes to the nucleotide sequence of the motif (as indicated by black arrows) in the A. baumannii umuDC(0636-0637) reporter strain and analyzing gene induction in response to treatment. Most highly conserved motif residues are underlined. The distance between the motif and the starting ATG is also indicated. bp; base pair (C) To analyze gene induction, the $u m u D C$ pr*-GFP strain was left untreated or treated with

$10 \times$ the MIC cip $\left(6.1 \mathrm{~g} \mathrm{~m} \mathrm{~m}^{-1}\right)$ during exponential phase and 1,000,000 cells were analyzed by FACS at T=0, 90 and 180 minutes. Alterations to the motif in the $u m u D C$ pr*-GFP reporter strain cause a great reduction of the dim subpopulation, as compared to the isogenic $u m u D C$ pr-GFP strain under the same conditions. (D) To compare induction in response to MMS, both the $u m u D C$ pr*-GFP strain and the $u m и D C$ pr-GFP strains were untreated or treated during exponential phase with $0.3 \times$ and $1 \times$ the MIC MMC (7.5 mM and $25 \mathrm{mM}$, respectively) and 1,000,000 cells were analyzed by FACS. Populations are largely unimodal with a decrease in bright fluorescence in the mutant strain. Histograms show cell number vs. fluorescent intensity

(FITC-A) over the time course. 


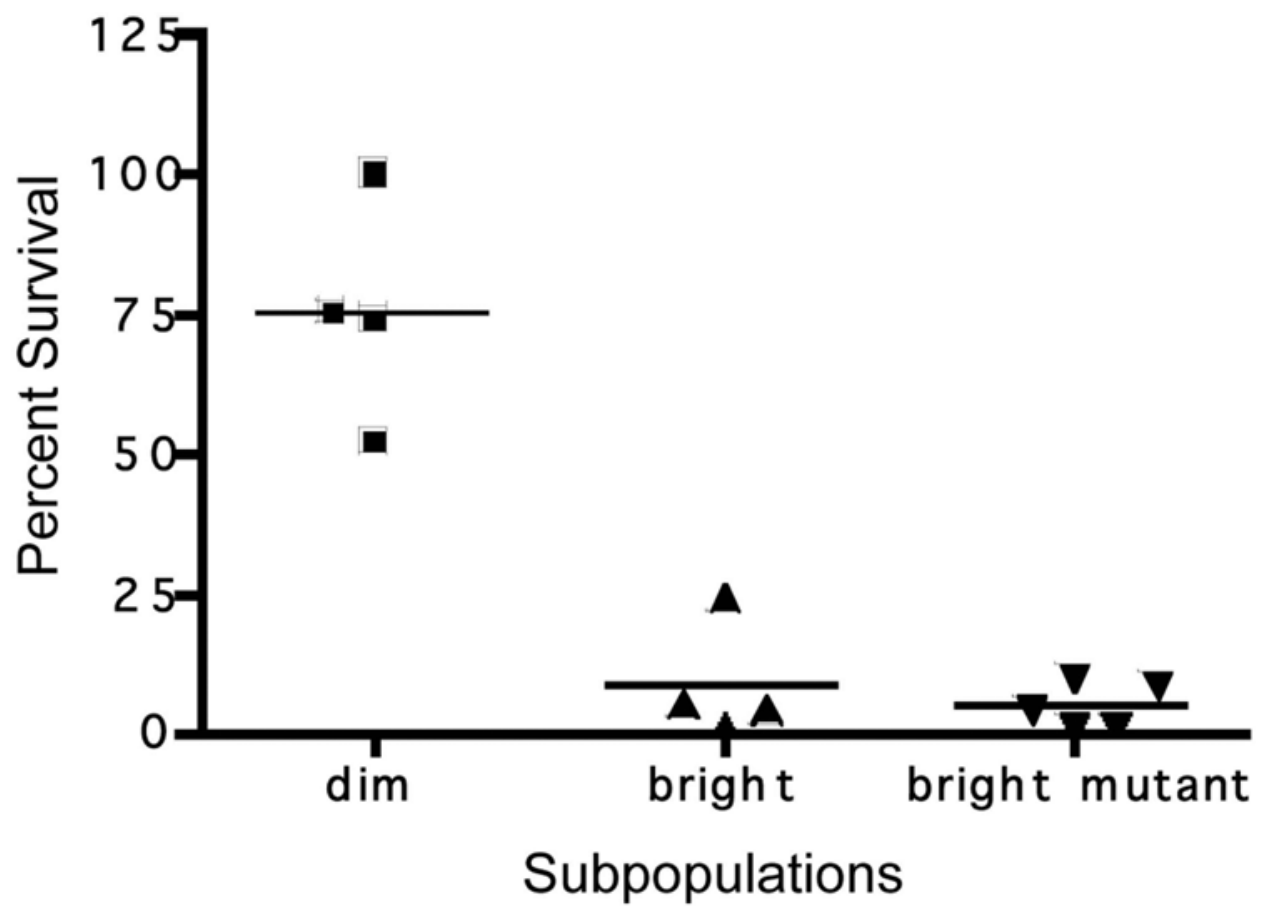

Figure 6. Dim subpopulation has 10-fold survival advantage over bright subpopulation after ciprofloxacin treatment A GFP transcriptional reporter for A. baumannii umuDC and umuDC (mutated promoter) were treated with $10 \times \mathrm{MIC}(6.1 \mu \mathrm{g}$ $\mathrm{mL}^{-1}$ ) cip during exponential phase for 180 minutes. Using FACS, cells were sorted into a dim and bright subpopulation, consisting of 250,000 cells each. These cells were then washed twice with SMO ( $\mathrm{NaCl} 0.85 \%$, Tris pH 7.5) and plated without treatment. Untreated cells were also sorted and plated to standardize the recovery of either the bright and dim sorted cells. The bright cells coming from the promoter motif mutant was treated and sorted as indicated above and plated on LB Kan. These were also standardized to untreated cells. Error bars indicate standard deviation of the mean for 5 (wild type cells) and 6 independent (mutant cells) replicates. On average, dim cells survive 10-fold more than bright cells during cip treatment. 


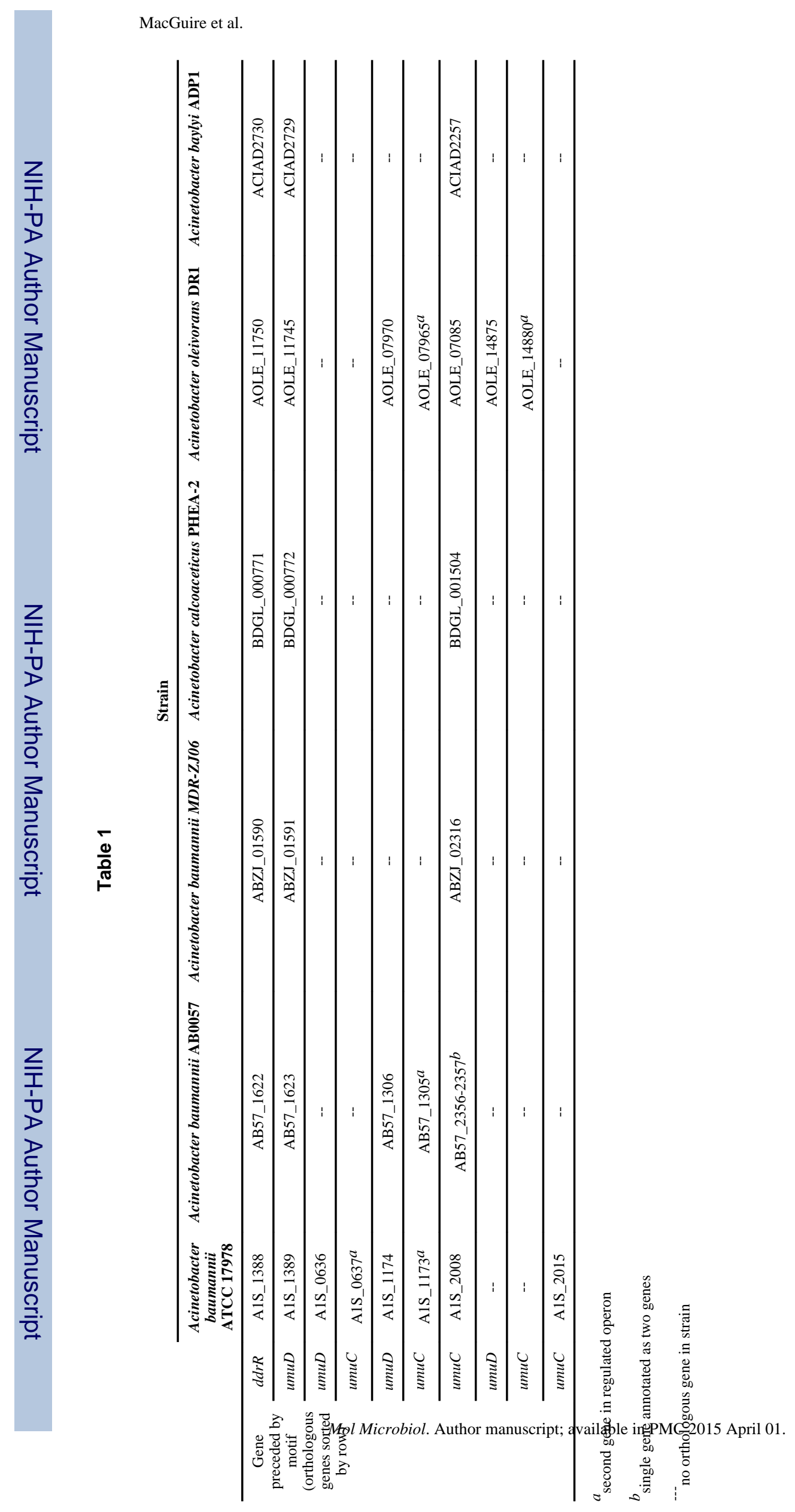




\section{Table 2}

Strains and plasmid used in this study.

\begin{tabular}{|c|c|c|}
\hline Strain/plasmid & Description & Reference \\
\hline Acinetobacter baumannii & ATCC17978, amp ${ }^{\mathrm{R}}$ & $\begin{array}{l}\text { American Type Culture } \\
\text { Collection }\end{array}$ \\
\hline Acinetobacter baumannii dinB & $\begin{array}{l}\text { As ATCC17978 with } \operatorname{dinB} \text { (A1S_0186) promoter-GFP fusion } \\
\text { on chromosome, } \operatorname{kan}^{\mathrm{R}}\end{array}$ & This work \\
\hline Acinetobacter baumannii umuDC & $\begin{array}{l}\text { As ATCC17978 with } u m u D C \text { (A1S_0636-0637) promoter-GFP } \\
\text { fusion on chromosome, } \operatorname{kan}^{\mathrm{R}}\end{array}$ & This work \\
\hline Acinetobacter baumannii uvrA & $\begin{array}{l}\text { As ATCC17978 with } u v r A \text { (A1S_3295) promoter-GFP fusion } \\
\text { on chromosome, } \operatorname{kan}^{\mathrm{R}}\end{array}$ & This work \\
\hline Acinetobacter baumannii recA & $\begin{array}{l}\text { As ATCC17978 with recA (A1S_1962) promoter-GFP fusion, } \\
\operatorname{kan}^{\mathrm{R}}\end{array}$ & This work \\
\hline Acinetobacter baumannii trpB & $\begin{array}{l}\text { As ATCC17978 with } \operatorname{trpB}\left(\mathrm{A} 1 \mathrm{~S} \_1692\right) \text { promoter-GFP fusion } \\
\text { on chromosome, } \operatorname{kan}^{\mathrm{R}}\end{array}$ & This work \\
\hline Escherichia coli dinB & $\begin{array}{l}\text { Escherichia coli } \mathrm{P} 90 \mathrm{C}, \mathrm{F}^{-} \text {ara }(\text { lac-proB })_{\mathrm{XIII}} \text { thi, with pUA66- } \\
\text { dinB-GFP, } \operatorname{kan}^{\mathrm{R}}\end{array}$ & $\begin{array}{l}\text { This work; plasmid from } \\
\text { (Zaslaver } \text { et al., 2006) }\end{array}$ \\
\hline Escherichia coli DinB-GFP & Escherichia coli $\mathrm{BW} 25513$, dinB-GFP & $\begin{array}{l}\text { This work. Strain from } \\
\text { (Datsenko and Wanner, 2000). } \\
\text { GFP gene from Kitagawa et } \\
\text { al., } 2005 \text {. }\end{array}$ \\
\hline Escherichia coli sulA (plasmid) & $\begin{array}{l}\text { Escherichia coli } \mathrm{P} 90 \mathrm{C}, \mathrm{F}^{-} a r a \Delta(\text { lac-proB })_{\mathrm{XIII}} \text { thi, with pUA66- } \\
\text { sulA-GFP, } \operatorname{kan}^{\mathrm{R}}\end{array}$ & $\begin{array}{l}\text { Benson et al., 2011B; plasmid } \\
\text { from (Zaslaver } \text { et al., 2006) }\end{array}$ \\
\hline Escherichia coli sulA (chromosomal) & $\begin{array}{l}\left.\text { Escherichia coli } \mathrm{P} 90 \mathrm{C}, \mathrm{F}^{-} \text {aras(lac-proB }\right)_{\mathrm{XIII}} \text { thi, with sulA-GFP } \\
\text { on chromosome }\end{array}$ & McCool et al., 2004 \\
\hline $\begin{array}{l}\text { Acinetobacter baumannii umuDC (altered } \\
\text { motif) }\end{array}$ & $\begin{array}{l}\text { As ATCC17978 with umuDC (A1S_0636-0637) promoter } \\
\text { (altered motif)-GFP fusion on chromosome, } \operatorname{kan}^{\mathrm{R}}\end{array}$ & This work \\
\hline pUA66 & $\mathrm{SC} 101$ ori, GFP reporter plasmid carrying $g f p m u t 2, \mathrm{kan}^{\mathrm{R}}$ & (Zaslaver et al., 2006) \\
\hline
\end{tabular}




\section{Table 3}

Oligonucleotides used in this study.

\begin{tabular}{|c|c|}
\hline Oligonucleotide & Sequence \\
\hline Abau $\operatorname{din} B \mathrm{pr}$ & 5'-GCAGCTCGAGGATCTGGAATATGACAGCAAC \\
\hline Abau $\operatorname{din} B \mathrm{pr}$ & 5'-GCAGGGATCCATTATTGTGCTTTCACGATGCC \\
\hline Abau итиDC & 5'-GCGCCTCGAGCTGGCACACCAAAGTTAATACA \\
\hline Abаи итиDC & 5'-GCCGGATCCGCTCCAATTCTGAATTAATTACTC \\
\hline Abau uvrA pr & 5'-GAGCCTCGAGTCTAAAATGTGTTGTCGTGTGGT \\
\hline Abau uvrA pr & $5^{\prime}$-CAGCGGATCCTCGAATACGGATATGACTTTGG \\
\hline Abau recA pr & 5'-GCGGCCTCGAGGATCACTGGTCTTATAATGATG \\
\hline Abau recA pr & 5'-GCATAGGATCCGCTTGAACAGTGTTATCACCA \\
\hline$A b a u \operatorname{trpB} \mathrm{pr}$ & 5'-GCCACTCGAGGTCGTAGGTGATGCCAGTAT \\
\hline Abau trpB $\mathrm{pr}$ & 5'-GGATGGATCCCTGGTGTATGGCGAATTTCT \\
\hline GFP R & $5^{\prime}$-CCATGGAACAGGTAGTTTTC \\
\hline pUA66 F & 5'-GCGTGCAATCCATCTTGTTC \\
\hline $\operatorname{din} B$ upstream & 5'-GCGAACATGGCTTTCATGTC \\
\hline $\operatorname{din} B$ gene $\mathrm{R}$ & 5'-GAGGGCATAGTTTTCTTGCT \\
\hline uтиDC & 5'-GCTAGAGTCTTTGAAGTGTG \\
\hline$u m u D C$ gene $\mathrm{R}$ & $5^{\prime}$-GCATGGAAAGGACATCCGTA \\
\hline$u v r A$ upstream & 5'-GTTGCCAAAGCTGTTCCATA \\
\hline$u v r A$ gene $\mathrm{R}$ & 5'-GCCGAAAGTGATTCGACATA \\
\hline recA upstream & $5^{\prime}$-GAAATTCGTGTCGGTATGGA \\
\hline recA gene $\mathrm{R}$ & 5'-GCTCAGCATCAATGAAGGCA \\
\hline $\operatorname{trpB}$ upstream & 5'-GCATGAACACATGGGACTTG \\
\hline $\operatorname{trp} B$ gene $\mathrm{R}$ & 5'-TATCAACTTGACCCATGTGG \\
\hline GFP gene $\mathrm{R}$ & 5'-TTTACTCGAGCCTCTAGAGCTTGCATGCCT \\
\hline$u m u D C$ gene $\mathrm{F}$ & $5^{\prime}$-AGCTGGCAATTCCGACGTCTGATTACGTTACGT \\
\hline$u m u D C$ gene $\mathrm{R}$ & $5^{\prime}$-GTGACGACTCCCCATACGAT \\
\hline Kan F & 5'-AGACGTCGGAATTGCCAGCT \\
\hline Kan R & 5'-ATCGCTGCAGATCAACAGGAGTCCAAGCGAG \\
\hline ECdinB-GFP 1 & 5'-CTCGCCAGGGGGTGAAATTAAAGTTCGACGATTTTCAGCAAACCACCCAGGAGCACG \\
\hline ECdinB-GFP 2 & 5'-CTCCAGCCTACACAATCGCTCTTATTTGTATAGTTCATCCATGCC ATGTGTAATCCCAGCAGC \\
\hline ECdinB-GFP 3 & 5'-GCATGGATGAACTATACAAATAAGAGCGATTGTGTAGGCTGGAG CTGCTTCGAAGTTCCTATACTTTCTAGAG \\
\hline ECdinB-GFP 4 & 5'-GCGAGAATTCGATGCATACAGTGATACCCTCATAATAATGCACA CCAGGCCATGGTCCATATGAATATCCTCC \\
\hline GFP A206K F & 5'-ATTACCTGTCGACACAATCTAAACTTTCGAAAG \\
\hline GFP A206K R & 5'-AGATTGTGTCGACAGGTAATGGTTGTCTGGTA \\
\hline \multicolumn{2}{|c|}{1,2 Primers contain XhoI } \\
\hline \multicolumn{2}{|c|}{${ }^{1}$ restriction site or BamHI } \\
\hline . & 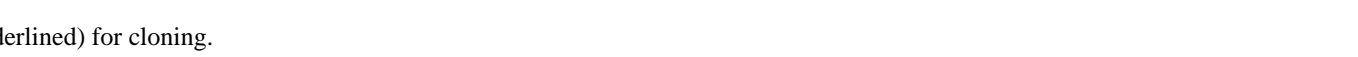 \\
\hline
\end{tabular}

